\section{Commonwealth Foundation}

The Commonwealth Foundation has produced its first progress report after 18 months of official activity as a charitable organization providing funds for professional bodies on a supra-national basis. The Foundation aims to encourage and support contacts and exchanges between members of the professions in the Commonwealth countries, through conferences, exchanges of personnel and information, and the setting up of Commonwealth-wide associations not centred on Britain. So far grants for nearly $£ 200,000$ have been allocated for sixty different projects throughout the Commonwealth. Accountancy, architecture, education, engineering, law and various aspects of medicine and scicnce have been supported, with amounts varying from 235 for publishing an accountancy bulletin in Zambia, to $£ 24,000$ for professional centres with basic reference libraries in Kampala and Port of Spain.

A meeting of representatives of the professions, arranged by the British Commonwealth Office in 1964, produced the idea for the Foundation. The proposal was announced at the Commonwealth Prime Ministers' Conference in June 1964; terms of reference were agreed in 1965 and, after appointment of a permanent staff of three, the Foundation became operational in March 1966. Twenty-four of the twenty-five Commonwealth countries contribute a quarter of a million pounds a year to the Foundation, at rates agreed to by the Prime Ministers concerned, to correspond with the size and affluence of each country.

Each contributing country is represented on the Board of Trustees, which has so far met five times, under the chairmanship of Sir Macfarlane Burnet. Applications for grants are accepted from individuals or professional bodies throughout the Commonwealth, for first consideration by the full-time director, $\mathrm{Mr}$ John Chadwick. Provided the applicant can produce good reasons for his application, and it falls within the terms of reference of the Foundation, it is passed to the Board of Trustees with the director's report. $\mathrm{Mr}$ Chadwick thinks the board will have to meet three times a year at least, and a sub-committee has been set up to consider applications which are urgent or for small sums of money. The main task of the staff in getting the Foundation has been to make its existence known, for individuals and professional bodies can only apply for grants if they know the facilities exist.

The Foundation, which describes its private but international set-up as "without precedent", is not stating its policy too firmly at this stage, and is prepared to experiment. A pilot project is under way in the field of journal distribution. The London Bureau of Hygiene and Tropical Diseases is collaborating with the Foundation to provide copies of the Tropical Diseases Bulletin for those in underdeveloped countries who cannot afford the subscription. The London bureau is pleased how quickly the Foundation accepted the scheme.

\section{Dragon Reprieved}

Tre Dragon high temperature reactor project will be kept in being for one more year at least. During 1968 , the costs of the project will be borne by the United Kingdom, Austria, Denmark, Norway, Sweden and Switzerland. The Euratom countries, the other supporters of the project, still have no firm policy for
1968 and thereafter. As a result, they have so far refused to extend the project until 1970. But they have at least been able to sanction an arrangement by which Austria, Denmark, Norway, Sweden and Switzerland pay their normal contributions to the 1968 budget of $£ 2.1$ million, with Britain making up the rest. It has also been agreed that Euratom will finally make up its mind by the end of July 1968 and, if approval to continue the project is reached, then the contributions made for 1968 will be taken into account. But if no agrcement is reached, Euratom will waive its rights to the written down value of the fixed assets of the project. Meanwhile, Euratom will continue to receive the same benefits, in the form of information and secondment of personncl to the project, as if it were paying its full share.

This generous settlement indicates a good measure of enthusiasm for the project among the non-Euratom countries. Some observers see the high temperature reactors as a good possibility for industrial use, able to produce electricity and high grade steam in reactor sizes smaller than would be economical with other reactor types. The news of progress with Dragon comes at the same time as the first experimental results from another high temperature reactor, the AVR, built in Julich by Brown Boveri/Krupp Reactorban $\mathrm{GmbH}$ for a group of German utilities. The reactor has so far run for about three months, most of the time well below its full design capability of about $50 \mathrm{MW}$ (thermal). The work has established that the system is safe, and approval has been given for full power opcration. Powers of $18 \mathrm{MW}$ (th) and helium outlet temperatures of $590^{\circ} \mathrm{C}$ have been reached.

\section{Living at High Altitude}

Some 30 million people throughout the world live above 10,000 feet-more than the total population of 85 per cent of individual nations. They live under perpetual physiological stress, that of hypoxiaoxygen shortage-often compounded by cold stress. Yet there is little systematic knowledge of the effect these conditions have on the high-altitude dwellers and the biological adaptations that are developed to cope-a situation thrown into relief by next year's Olympic Games in Mexico City, which lies at 7,349 feet.

To counter this lack and promote useful research programmes the regional office of the World Health Organization and the US International Biological Programme Committce jointly sponsored an international conference on "Man at High Altitude" in Washington last month. The study of high altitude peoples is of great interest to the Human Adaptability Section of IBP. The conference hardly threw a glance at the problems of Olympic athletes, but a couple of papers were relevant to this practical problem as they discussed the relation of oxygen uptake and work capacity.

Dr R. F. Grover of the University of Colorado has compared lung function and working capacity of athletes from two groups; one, a community settled for several gencrations at Leadville 2 miles up in the Rockies, the other a group from lowland Kentucky. It was found that maximum capacity for consuming oxygen at Leadville was reduced as much in the Leadville native athlete as in the Kentucky athlete. Dr Grover wondered whether the long-adapted Andean 
native (Peruvians have lived at about $10,000 \mathrm{ft}$. for thousands of years) would be physically superior (at altitude) to the well conditioned athlete from the lowlands. Among Leadville non-athletes, hypoventilation (shallow breathing) was common.

This seems a regular characteristic of those highland communities which have been most thoroughly studied. Dr John W. Severinghaus of the University of California San Francisco Medical Center described work on Peruvian Indians which indicated that the native who has always lived at high altitude does not breathe more deeply in a diminished oxygen atmosphere whereas a sea-level native who goes to the highlands does. Dr Severinghaus suggests that the highlander has lost sensitivity in the chemo-receptors governing this reflex. This may have very far-reaching consequences: longevity, intelligence, learning, fertility, infant survival, susceptibility to respiratory diseases may all be implicated. This reflex loss appears to tie in with the characteristic health hazard of high altitude, pulmonary oedema. This was by far the most common affliction of the several thousand Indian troops who have been stationed on the Himalayan border between 11,000 and $18,000 \mathrm{ft}$. since the 1962 emergency. Dr Inder Singh, in discussing the clinical problems encountered by the Indian forces medical services in the area, reported that diuresis induced by drugs has been found to relieve the condition.

A number of recommendations for both research projects and for practical action were adopted by the meeting. One was the preparation of a short, concise book on high altitude medicine to cover high altitude diseases, modification of common sea-level diseases at high altitude, as well as the modification of drug and anaesthetics action. It was also agreed to found a research centre of high altitude studies to act as a clearing house for information on the subject and improve scientific communication in this field.

\section{Manpower for Electronics}

A contunding shortage of scientific and technological manpower is envisaged in the electronics industry, together with a growing demand for engineering skills. These and other findings of the enquiry undertaken by the Manpower Research Unit, in association with the Electronics Economic Development Committee, are presented in Electronics-the fifth in a series of reports by the Manpower Research Unit (HMSO, 6s. $3 d$.$) . The purpose of the enquiry was to gain a$ clearer picture of likely manpower developments within the industry up to and beyond 1970, and forty-six firms participated.

According to estimates made by the Ministry of Labour, 371,000 people were employed in the electronics industry in June 1965-288,000 were in electronics and 83,000 were in telecommunications. Shortages of labour were common throughout the industry. The over-riding factor in determining the size of the labour force-not surprisingly, perhaps-was the level of demand for products. The development of microcircuits, the report says, calls for more support at technician level, while the development of printed circuits and semi-conductors would probably involve less mechanical assembly and a move from male to female assessors.

Most firms, it is reported, thought that technological change, including the use of computers for planning and managerial control, would be the principal means of increasing productivity. Incentive schemes were favoured by some firms but criticized by others and other important contributions to productivity were expected from work and methods study, training and standardization of production.

Estimates were made of changes in the occupational structure of the industry between 1965 and 1970 and an increase in the employment of scientists and technicians is expected in the fields of radio and other electronic apparatus and in telecommunications. Shortage of production engineers, systerns and circuit engineers and computer staff was particularly evident at the time of the enquiry, and it was suggested that, although in general the basic cause of shortages was the rapid expansion of the industry and the rate of technical change within the individual firm, the most important fact was the continuing transfer of scientists and technologists to managerial posts. Furthermore, the report suggests that there is a need to encourage more young people to take up science and engineering and the "one-way traffic" of graduates into the academic field is criticized.

\section{Parliament in Britain}

\section{Nuclear Ships}

MR A. WEDGwood BenN, Minister of Technology, has agreed to consider the recommendation of the Select Committee on Science and Technology that a departmental committee be convened to examine the possibilities of nuclear marine propulsion. He pointed out that the responsibility for the Atomic Energy Authority, the nuclear industry, the manufacture of marine engines and shipbuilding had all been placed on his department. It was in touch with all the interests concerned and he intended to re-examine the position to ensure, as far as possible, that Britain was in a position to embark on a major project as soon as it appeared that commercial demand for such ships justified the considerable cost involved. (Written answer, December 5.)

\section{Patents}

IN a debate in the House of Commons on November 30, Mr C. Fletcher-Cooke and Sir Lionel Heald challenged the idea that the Patent Office and the Trade Mark Registry should be self-supporting. Mr FletcherCooke maintained that Parliament had never said that they should pay their way and argued that the increase in fees proposed for filing patent applications, complete specifications, trade marks and their renewals was unjustified and constituted a discouragement to invention. Sir Lionel Heald questioned the organization and efficiency of the Patent Office. Had any real effort been made to produce a more modern and efficient system ? The Minister of State at the Board of Trade, Mr G. Darling, who replied for the Government, did not think that the increased fees would discourage applications, and pointed out that on an average the Patent Office spent $£ 55$ on each application against the $£ 15$ which would now be received and that 70 per cent of all applications came from overseas. He paid tribute to the efficiency of the Patent Office and its staff. He would be glad, he said, to see it moved from its present premises, but he did not think it should be run at a loss. (Debate, November 30 .) 